\title{
TITLE: The French Connection: Complicity in the 1994 Genocide in Rwanda
}

\author{
Hazel Cameron \\ University of St Andrews
}

\begin{abstract}
:
This article explores the French government's political and military relationship with Rwanda since 1975, with a particular focus on the period from 1990 and throughout the genocide of 1994. An argument is made that the French state, through its behaviour in Rwanda before and during the genocide of 1994 is complicit under international criminal law. As a concept, complicity provides a lens for understanding the scope of liability of states as responsible actors within the international system. The article argues that that the knowing participatory role played by the French throughout the period of the Rwandan genocide, can be construed as complicity in genocide. This is a criminal breach of international law.
\end{abstract}

\footnotetext{
"The more one looks, the more one finds examples in the recent history of genocide of minority groups whose fate hinges on their historic connection with Western, usually former imperial powers" 1
}

Four years after the Rwandan genocide of 1994, the French Assembly issued a report on its investigations into the killings. In doing so, the main Rapporteur of the report confidently asserted that, in relation to genocide, 'France is neither responsible nor guilty'2. This statement contradicted the actual evidence presented to the panel, but which was ignored. As the Organisation of African Unity (OAU) caustically noted, '[t]he [French Assembly] report's evidence and the report's findings seemed unrelated'3. In addition to such contradictions with the basic facts about the genocide, significant aspects of French involvement in Rwanda were omitted from the inquiry from the start. Foremost of these was an indicative picture of French military assistance to Rwanda throughout the 1990s until the end of the genocide of the Tutsi in 1994. Such a portrayal would have provided a contextualisation of France's 
historic role in Rwanda. It would however, have meant that French denials of involvement in the 1994 tragedy were even less credible.

This article utilises in-depth semi-structured interviews that the author conducted with genocide survivors ${ }^{4}$, Rwandan government officials, British government officials and former representatives to the United Nations Security Council (UNSC). The evidence presented demonstrates that the French government as a collective responsible entity is accountable and criminally responsible for its failure to act to prevent or stop the Rwandan genocide. This argument directly contradicts the French government's refusal to acknowledge even its minimal role in the atrocities. The interviews were further supplemented with data drawn from interviews with ex- Forces Armees Rwandaise (FAR), former Interahamwe ${ }^{5}$, and genocide survivors screened at the Mucyo Commission', in addition to biographies, official reports and newspapers. Analysis indicates that the knowing participatory role played by the French throughout the period of the Rwandan genocide can be construed as complicity in genocide, a criminal breach of international law.

\section{International Criminal Law and Complicity}

Central to any discussion on the law of genocide and the subject of this article is the International Convention on the Prevention and Punishment of the Crime of Genocide (hereinafter Genocide Convention)7, which the United Nations adopted on December 9, 1948, and which entered into force on January 12, 1951. The Genocide Convention is an international treaty embraced by the realm of public international law, which draws on elements of international criminal law, international humanitarian law and international human rights law ${ }^{8}$. As the International Court of Justice noted in its 1951 advisory opinion, 'the principles underlying the Convention are principles which are recognized by civilized nations as binding on States, even without any conventional obligation' ${ }^{9}$.

The jurisdiction of the Genocide Convention extends in Article III to include conspiracy to commit genocide, and complicity in genocide. These are classed as crimes under international law. The Genocide Convention is supplemented by later legal processes. The Statutes of both the International Criminal Tribunal for the Former Yugoslavia (ICTY) and the International Criminal Tribunal for Rwanda (ICTR) contain two notable provisions on responsibility for genocide. These are 'complicity' in genocide and 'aiding and abetting genocide'. The prosecutor of the ICTY argued that 'any assistance, even as little as being involved in the operation of one of the camps', constitutes sufficient participation to meet the terms of complicity ${ }^{10}$.

It must be underlined that negligence is incompatible with the specific intent requirement of genocide. ${ }^{11}$ As the ICTR observed in the Akayesu case ${ }^{12}$, an individual cannot be guilty as a participant in genocide 'where he did not act knowingly, and even where he 
should have had such knowledge ${ }^{\prime 13}$. Schabas defines complicity in genocide as incriminating those who 'aid, abet, counsel and procure, or otherwise participate in criminal offences'. ${ }^{14}$ The proceedings of the ICTR in the case versus Akayesu have been interpreted as 'aiding' being defined as giving active assistance to someone, whilst 'abetting' involves facilitating the commission of an act by being sympathetic thereto. ${ }^{15}$ Following this, the concept of complicity in genocide has been developed in international jurisprudence to enable the prosecution of those who knowingly assist, aid, abet, procure or counsel genocide, but who never actually wielded the machetes, guns, or other tool of genocide and thus were not directly responsible for actual crimes. This notion of complicity can, it is argued, be extended beyond individuals to include corporate actors such as states. Such an argument springs from the growing literature on the notion of state crime.

\section{The concept of state crime}

Historically, criminal responsibility of the state is a concept that has been challenged by proponents of a strict reading of state sovereignty. ${ }^{16}$ Such a legal positivist position would argue that as it is states that make laws, states cannot-by definition-break the law. Such a tautological argument of course privileges the state (and its actors) above and beyond responsibility for their actions. This logic was questioned at the post-war Nuremburg Trials but lay in abeyance for decades during the Cold War as realpolitik triumphed. However, an emerging consensus developed after the end of the Cold War and now can be said to exist that argues that states can commit crimes and that they should be held criminally responsible for such legal breaches. Whilst this consensus is largely academic thus far, state responsibility for international crimes can be said to be an emerging normative principle within international law. ${ }^{17}$ With this regard, the concept of states being responsible for breaches of international criminal law was formally adopted in Part I of the United Nations International Law Commission's Draft Articles on State Responsibility. ${ }^{18}$ Indeed, the ICTR achieved several convictions on charges of complicity in genocide. ${ }^{19}$ However those precedents, without exception, involved complicity by individuals as opposed to complicity by states.

Contraventions of Article III of the Genocide Convention have to date been levelled solely at individuals and although there is an affirmation within the Genocide Convention that states may not fail to act in the face of mass atrocities directed at the destruction of a particular group, no state has yet been held accountable in terms of the Genocide Convention. It is argued that this is logically incompatible with the accepted norm of complicity and that the role of the French in the 1994 genocide in Rwanda is a clear example of this. Why this is so, is discussed below.

The subject of direct responsibility of states for genocide, in addition to state responsibility should they fail to prevent or punish acts of genocide, was debated during the 
conceptualisation phase of the Genocide Convention, when the United Kingdom proposed an amendment to Article V. The amendment stated that '[c]riminal responsibility for any act of genocide as specified in Articles II and IV shall extend not only to all private persons or associations, but also to states, governments, or organs or authorities of the state or government, by whom such acts are committed' [italics emphasised]. The amendment was however rejected, ${ }^{20}$ and the ambiguous wording of Article IX, intimating the potential responsibility of a State for genocide or any of the other acts enumerated in Article III, continues to be the subject of much close examination and debate. Interestingly the International Court of Justice's interpretation of Article IX of the Genocide Convention does not exclude any form of state responsibility. Nor was the responsibility of a state for acts of its organs excluded by Article IV of the Convention, which contemplates the commission of an act of genocide by 'rulers' or 'public officials'. ${ }^{21}$ This opens up the possibility of state complicity. ${ }^{22}$

In 2001, the United Nations International Law Commission produced 'Draft Articles on State Responsibility' for intentionally wrongful acts, which were subsequently adopted and received by the United Nations General Assembly in $2001 .{ }^{23}$ Crawford et al argue that this is one of the most important topics that the Commission has undertaken. ${ }^{24}$ Article 19 of the said 'Draft Articles on State Responsibility' recognized the possibility of genocide being committed by a state but that this would constitute a 'wrongful act', taking the form of a state's breach of a fundamental treaty obligation, as opposed to a criminal act. ${ }^{25}$ However, of significance is that the said Articles were quite explicit in stipulating that wrongful acts by persons in authority may be attributed to the States they serve. Under Article 8, acts committed by individuals 'shall be considered an act of State under international law if the person or groups of persons is in fact acting on the instructions of, or under the direction or control of, that State in carrying out the conduct' [emphasis added] ${ }^{26}$. In addition, Article 9 adds that 'the conduct of a person or group of persons shall be considered an act of State under international law if the person or group of persons is in fact exercising elements of governmental authority in the absence or default of the official authorities and in circumstances such as to call for the exercise of those elements of authority'27 [emphasis added]. The International Law Commission's Draft Articles on State Responsibility thus lays bare the principle that the state that empowered actors can be held directly accountable for the acts of these empowered individuals. This normative principle is extremely important and having established the legal definition and parameters of state complicity, we now turn to the Rwandan case and the role of France.

\section{Franco-Rwandan relations}

Rwanda was first occupied by the Germans in the 1890s, thereafter by Belgium after the First World War (under a League of Nations mandate) and until independence in 1962. After the 
Belgians withdrew from the country in 1962, their only interest in Rwanda was to nurture an economic relationship as opposed to political and military links, which were gradually assumed by Paris. Indeed, France effectively stepped in to take advantage of the cultural and linguistic roots already formed during Belgian rule, and Rwanda found itself being slowly incorporated into la Francophonie and Françafrique. This process accelerated as the 1970s unfolded.

From the beginning of the presidency of Major General Juvenal Habyarimana in 1973 (he assumed power via a coup d'etat), France assiduously courted Kigali and the Rwandan political elite. In 1975, a Franco-Rwandan military cooperation and training agreement was signed in Paris by Presidents Valéry Giscard d'Estaing and Habyarimana. ${ }^{28}$ The agreement stated that' $[t]$ he government of the French Republic places at the disposal of the government of the Rwandese republic the French military personnel whose services are required for the organisation and instruction of the Rwandese national police' ${ }^{29}$ The agreement was a classic example of the way in which France tied in African states to the broader French sphere of influence across the continent. '[D] espite an Organisation of African Unity (OAU) resolution in 1978 condemning the existence of foreign military bases on the [African] continent', ${ }^{00}$ the French military persisted, maintaining 400 coopérant forces in Rwanda throughout the 1980s. Whilst African sensibilities rejected the idea of foreign militaries being stationed in and operating on a postcolonial Africa, individual states - particularly in Francophone Africahad lesser qualms. Such forces were a visible show of support by Paris for its clients and Habyarimana was no exception. Indeed, France acted as a visible guarantor for the regime and this continued up to and beyond 1994. The increasing institutionalisation of ethnicity and autocracy had no visible effect on France's enthusiastic support for Kigali. Indeed, it can be argued that this support actually helped facilitate Habyarimana's project in making Rwanda one of the most controlled and restrictive non-communist states in the world. ${ }^{31}$ The 1978 constitution in fact institutionalised an ethnically based one party state, Ethnic divisions were entrenched by this constitution in pre-genocide Rwanda which was wholly acceptable to the French.

In fact, under President François Mitterand (1981-1995), relations with the government of Juvenal Habyarimana intensified, with France increasingly playing a role in shaping Rwanda's economic and social relations as well as its political power structures. Whilst the presidential campaign of Mitterrand had promoted a 'new way' in France's view of the world and had presented an ostensible ethical foreign policy that 'pledged to defend the rights of the oppressed people everywhere, champion a fairer system of international development and work for world disarmament', very little practically changed in Franco-African relations. ${ }^{32}$ Interestingly, Mitterand portrayed himself as an ardent proponent of reducing France's sale of armaments to Africa. Yet at the time of Mitterand's inauguration in 1981, France was the 
leading arms exporter per capita in the world and the French arms industry had no such ethical ambitions. Mitterrand's policy of supporting the 'poor and oppressed' was short-lived and arms sales to regimes with questionable human rights records thrived. ${ }^{33}$ In fact, Mitterrand was to subsequently prove to be Rwanda's closest military and political ally.

\section{French military intervention in Rwanda: Operation Noroît}

French military numbers in Rwanda soared as a result of Operation Noroît, a French operation launched in response to a request for assistance by President Habyarimana against a surprise $R P F$ invasion from Uganda on 1 October 1990. The RPF attack was quickly repelled by FAR with the assistance of French military support and the RPF retreated, subsequently launching a series of guerrilla incursions into Rwanda that were met with rapid retaliatory action by the Rwandan army, again ably assisted by the French.

After the RPF defeat, Habyarimana's regime reacted by staging indiscriminate attacks on Rwandan civilians and thereafter issuing press releases identifying RPF infiltrators as the perpetrators. This then provided a pretext for arresting numerous Tutsi civilians suspected of supporting the RPF. These detainees would be held without charge, thousands of them for months and in conditions where many were tortured and dozens died.

Since these events, it has been argued that the French military involvement in Operation Noroît was responsible for escalating the levels of Rwandan government brutality and 'encouraging further purchases of military hardware at the expense of basic necessities' within the country. ${ }^{34}$ That this occurred under France's watch is clear: according to Human Rights Watch, from the beginning of the outbreak of civil war in 1990, the French authorities were fully aware of the risk of genocide in Rwanda but did nothing. ${ }^{35}$ Whilst the ostensible purpose of Noroît was as a humanitarian mission to protect Europeans in danger, a clandestine element within the operation called Panda DAMI (Détachement d'Assistance Militaire et d'Instruction) provided direct support to the Rwandan army and was involved in combat versus the RPF. ${ }^{36}$ In short, Paris actively involved itself in an African civil war and chose sides.

After repelling the RPF's October 1990 attack and thus the alleged threat to Europeans was over, the French troops of Operation Noroît remained in Rwanda. ${ }^{37}$ This presence enabled French troops to become officially involved in organising and training members of FAR and the specially recruited Presidential Guard. Whilst this would be compatible with the treaty signed between Paris and Kigali, there is corroborated evidence that the French military were also responsible for actively training thousands of the civilian Hutu militiamen of the Interahamwe and the smaller Impuzamugambi. These individuals would later become the main perpetrators of the genocide. As the militia were party-aligned and non-governmental, there was no justification for the French military mission in Rwanda to be involved in 
training such groups. Paris was well aware of this. The Franco-Rwanda agreement of 1975, clearly specified that the French military were only legally permitted to organise and instruct the Rwandese national police. ${ }^{38}$ In order to legally cover French support for Habyarimana's military, the 1975 Franco-Rwandan agreement was amended on 26 August 1992 to allow training of the Rwandese Armed Forces. ${ }^{39}$ But this amendment never legally permitted the French to train party militias. ${ }^{40}$

A resident in Rwanda throughout the period 1990 - 1994, personally witnessed the French supply FAR with Panhard armoured cars, heavy artillery and some Gazelle helicopters. ${ }^{41}$ Indeed, a former soldier of FAR stated that 'in 1990 the French came with the guns and taught us how to use them. The French soldiers went into battle with us, fighting the RPF, but it was only the French that fired the heavy guns.' ${ }^{42}$ Operation Noroît officially left Rwanda in December 1993. However a significant number of witnesses have affirmed that the French military remained in Rwanda covertly and continued military training up to and throughout the period of the genocide the following year ${ }^{43}$.

During the period of Operation Noroit, French influence was not restricted to the physical coaching in target practice with firearms or even the art of strangulation and the construction of wooden clubs. In fact, the French also provided their students with ideological indoctrination infused with an eliminationist agenda directed against the Tutsi. France maintained a permanent diplomatic mission in Kigali during this time, allowing the embassy to keep abreast of the hate propaganda broadcast over the airwaves and printed in newspapers by the regime and extremist Hutu Power ideologues, as well as the persistent massacres committed by elements who would later became perpetrators of genocide. ${ }^{44}$ There is no evidence that France sought to rein in such pronouncements; to the contrary, there is ample confirmation that the French were involved in encouraging such discourses.

A former Rwandan soldier has stated that ' $[t]$ he French soldiers would teach us that the Tutsi were our enemies and that we should kill them at any opportunity. The French taught us that if we allowed the Tutsi to return, they would take over our country. They would cause us to perish. ${ }^{45}$ Another former Rwandan soldier has testified that the French told them 'your enemy is the Tutsi. As long as they are alive, the Hutu will never be comfortable. Figure out a way of killing them and finishing them.' ${ }^{46}$ A former commander of the Interahamwe, currently serving a life sentence in a Kigali prison, claimed when interviewed in 2015 that he was trained by French troops (along with 700 others drawn from the Kigali area), who taught him how to kill people with machetes and guns. The training lasted 8 months. At the time, he suspected that such training was to enable genocide of Tutsi. ${ }^{47}$ During the actual genocide, numerous witnesses and photographic evidence substantiate the fact that French soldiers directly assisted Rwandan army units ${ }^{48}$ and indeed an investigation by Human Rights Watch 'observed French soldiers manning checkpoints... They were armed with 5.56mm FAMAS 
automatic rifles, as well as Wasp 58 assault rocket launchers and other infantry support weapons. Like Rwandan army troops, French troops demanded identification [cards] from passing civilians.' ${ }^{49}$ The aforementioned Interahamwe commander confirmed that after the killings began, his group was accompanied by four French jeeps with about 20 French soldiers. These French soldiers did nothing to stop the murders. "They could have stopped us, but they didn't" stated the commander. ${ }^{50}$

It should be pointed out that these developments coincided with Rwanda being SubSaharan Africa's third-largest importer of weapons in the two years prior to the genocide, quite a feat for one of the smallest countries in Africa with a land area of just 9,633 sq miles. ${ }^{51}$ Human Rights Watch claim that although not the sole supplier, it was the French who delivered the decisive military supplies and telecommunications equipment to the regime in Rwanda that later played an integral role in the genocide. ${ }^{52}$ Given the very close relationship between Paris and the government in Kigali, as well as the strong French diplomatic presence in the country, it is inconceivable that France did not know was unfolding. Ex- Interahamwe have claimed that Paris' longstanding relationship with the Rwandan regime explained the French role in the genocide.

\section{Operation Amaryllis}

Within hours of the death of President Juvenal Hayarimana in Kigali on the evening of 6th April 1994, civil war mutated into genocide in Rwanda, with roadblocks being established and pre-prepared lists of targets for murder being distributed. ${ }^{53}$ As violence raged, the French government, in coordination with other countries launched Operation Amaryllis, an evacuation mission to remove all European citizens from Rwanda. The operation was active between 8-14 April 1994. It needs highlighting that the first evacuees from Rwanda by French forces were Madame Agathe Habyarimana, the widow of the President, and thirty members of her family. To this day, this group remain genocide suspects and stand accused of being responsible for crimes against humanity. ${ }^{54}$ As this is written, these individuals continue to enjoy the protection of the French state. In contrast, Tutsi members of staff at the French embassy were abandoned by the French, most being killed by the génocidaires. ${ }^{55}$

The Belgian Col. Luc Marchal who was second in command of UNAMIR told the BBC, and later confirmed to Le Monde (23 August 1995), that one of the French planes supposedly participating in the evacuation operation Amaryllis arrived at 0345 hours on 9 April with several boxes of ammunition. The boxes, about 5 tons, were unloaded and transported by FAR vehicles to Kanombe military camp near Kigali airport, where the Rwandese Presidential Guard was quartered. The French government denied this, saying that the planes carried only French military personnel and material for the evacuation. The Interahamwe leader recently interviewed in prison in Rwanda confirms that the French did deliver a large 
quantity of weapons to Kigali by air in the days immediately following the assassination of President Habyarimana, many of which were thereafter distributed to Interahamwe ${ }^{56}$ Only after this did the French soldiers present revert back to their role of evacuating Europeans out of Rwanda. ${ }^{57}$

Deliveries of arms from France to the regime continued throughout the period of the genocide and indeed, one former member of the Interahamwe has stated that as a French shipment of arms was being unloaded from a French military plane at Goma airport, the French were assuring them '...you cannot be defeated because we support you'. The génocidaire adds that 'Once we unloaded the planes we were issued with the weapons and boarded onto buses at Goma to be taken to Kigali or some other place' to engage in the killings. ${ }^{58}$

On 17 May 1994, a United Nations arms embargo mandated a halt to all arms shipments to Rwanda. ${ }^{59}$ However, as late as 18 July 1994 arms originating from France were still being delivered to the Hutu regime, which was now in exile in Zaire, another client state of the French. These arms transfers were conducted under the guise of Operation Turquoise (see below). ${ }^{60}$ The sheer scale of French arms sales to Rwanda in the period immediately before and during the genocide played a major role in sustaining and escalating the violence. ${ }^{61}$ The question of complicity clearly arises simply with reference to these weapons shipments.

\section{Ending a genocide}

By the end of May 1994, the RPF controlled most of eastern Rwanda and had put a halt to the genocide in this area. Human rights organisations and the media had by this time become aware of what had unfolded. Even the French Foreign Minister, Alain Juppé, was compelled to acknowledge that the events in Rwanda constituted 'genocide' ${ }^{62}$ That it was genocide committed by a close ally of Paris was elided. By this point in time, it was becoming evident that the RPF were close to toppling the regime in Kigali and achieving military victory. In full knowledge of these conditions, the French government put forward a resolution to the United Nations Security Council (UNSC) for a self-funded 'humanitarian intervention' in Rwanda codenamed Operation Turquoise. Resolution 929 was authorised by the UNSC on June 22 1994, providing the French intervention with an aura of authenticity. The Operation was described by France as 'a temporary multinational force' to establish secure humanitarian areas and its deployment was limited to two months. ${ }^{63}$

Operation Turquoise was granted a Chapter VII mandate by the UNSC, which allowed the use of 'all necessary means, including the use of force'. Repeated requests throughout the previous two months by the UNAMIR Force Commander Romeo Dallaire to have his Chapter VI mandate amended to a Chapter VII operation permitting the similar use of force were continually rejected by the UNSC as the genocide unfolded. Yet as soon as Paris 
observed that its client regime was about to be removed, Paris sprang into action. In fact, Dallaire strenuously opposed the authorization of the second UN mandated mission, later stating that 'I was concerned about there being two missions in one country with conflicting mandates but ultimately I knew the French were using a humanitarian cloak to intervene in the country for their own ends. ${ }^{64}$ One former British Ambassador to Rwanda has later averred that ' $[t]$ he real blinder the French played was to get Security Council agreement to this [resolution 929]'.65

There was in fact distinct apathy within the UNSC to Resolution 929, with five abstentions out of a total of fifteen council members. Few on the Security Council believed that France was motivated by strictly humanitarian concerns. ${ }^{66}$ The general opinion within the UNSC was that it was unimaginable that France had had 'a crisis of conscience' and much more believable that it was about to use the cover of the UN to protect French interests in Rwanda and save Hutu génocidaires from retribution ' ${ }^{67}$ One former British Cabinet member of 1994 has noted that 'there were other reasons [for the intervention]... any humanitarian consequences of the deployment were purely a by-product' ${ }^{68}$ Yet such actors facilitated the mission.

The United Nations authorization of Resolution 929 raised much domestic cynicism within France, with newspapers printing scathing allegations about its government's deliberate collaboration in the planning and implementation of the genocide in Rwanda. A front-page cartoon in one French newspaper showed French troops carrying medical supplies into Rwanda. Standing nearby on top of a box of arms and ammunition is an African firing an automatic weapon at other Africans. One of the French soldiers is pictured shouting to his comrades: "The problem is that they're armed to the teeth." On the munitions box are the words "Made in France"69. Early on, civil society within France (or at least parts of it) fully understood Paris' role.

In addition to the French military, a few hundred troops from Senegal and Chad, and about forty from the Republic of Congo and Niger, supported Operation Turquoise. Dallaire argues that 'this was solely to give it an aura of multilateralism, but it was far from this' ${ }^{70}$ Given the well-known workings of Françafrique, this is most likely an accurate statement and fits in fully with French practice since the days of independence. The day after UNSC Resolution 929 was passed the French military arrived in Rwanda, heavily armed with mortars, light and heavy machine guns, helicopters, fighter-bombers, ground attack planes, reconnaissance planes and more than one hundred armoured vehicles. However the Force Commander of UNAMIR noted that there were very few trucks and those trucks present had no lift capabilities such as would be required for a notional humanitarian intervention. This led him to believe that this was primarily a military intervention, despite the stipulation by the Security Council that the intervention was for humanitarian purposes only. ${ }^{71}$ 
One genocide survivor who was in hiding in Kigali at the time has stated that the Interahamwe militia, responsible for the majority of the atrocities, 'gave the French a very warm welcome. There was much shouting and dancing in the street and French tricolours being waved around and the flags were hung even on the Rwandan Army military vehicles. The killers were shouting "Vive La France". ${ }^{72}$ If the Interahamwe believed that French troops had arrived to stop their activities, this is a strange response. In fact, rather than quashing the massacres and drawing a halt to genocide in Rwanda, the arrival of the French troops buoyed the spirits of the near-defeated génocidaires who now felt protected by the arrival of their long term ally and reinvigorated to complete their task of exterminating the few remaining Tutsi. Indeed the arrival of the French military in June 1994 actually facilitated further massacres to continue unchecked for an extra month. The ex-Interahamwe commander cited earlier stated that the French actively helped him escape to Zaire. This individual was later convicted of Category Two genocide crimes at Gacaca, as defined in the Organic Law 08/96 of August 30, 1996, namely being a person whose criminal acts or whose acts of criminal participation place them among perpetrators, conspirators of accomplices of intentional homicide or of serious assault against the person causing death.

With the arrival of Operation Turquoise, the Force Commander of UNAMIR and members of FAR actually recognised many of the French soldiers and commanders as having previously been garrisoned in Rwanda with Operation Noroît. ${ }^{73}$ This was confirmed by the subsequent French Parliamentary Commission report on Rwanda (1998), which conceded that the use of such troops 'without doubt created a source of ambiguity and encouraged mistrust and scepticism'. ${ }^{74}$

Witnesses have testified that, contrary to their alleged humanitarian mandate, French soldiers involved in Operation Turquoise actively killed Tutsis trapped at the Interahamwe roadblocks. Clementine Gatete, a Tutsi survivor of Kigali has stated that 'yes, the French did genocide and they helped people who did genocide...During the genocide they would help the Interahamwe with the roadblocks and check the identity cards to try and catch Tutsi civilians' ${ }^{75}$ One ex-FAR soldier who worked alongside members of the French intervention force has stated that, 'I did not see French soldiers shooting openly, but when they captured Tutsi at roadblocks they would put them into their trucks and drive them to the barracks. The people caught on the roadblock were never seen again' ${ }^{76}$ According to Didier Gasana, who joined the Interahamwe before the start of the genocide, Tutsi prisoners arrested by the French at roadblocks were killed and loaded into trucks by the militias and the bodies dumped in Lake Vert. He claims that six French soldiers provided a military escort for the trucks carrying the corpses of the Tutsi. ${ }^{77}$

Evidence has also been obtained of soldiers deployed by Operation Turquoise torturing persons suspected of being RPF members (often merely being Tutsi "justified" such 
suspicions). Interviewees, including a former soldier with the Rwandan army, and a former Mayor in Karama Commune, state that they saw the French soldiers arresting people at roadblocks during the genocide. 'They tied them up and then beat them badly. They then took them by helicopter to Nyungwe forest and pushed them out of the choppers from the air [whilst they were still alive]'. ${ }^{78}$ Indeed, Celestin Mutangana survived being tortured by the French and then being thrown from one of their helicopters. When interviewed he displayed visible scarring to his body. ${ }^{79}$

\section{Operation Turquoise in Bisesero}

By mid-June 1994 there were few Tutsi left to rescue in Rwanda, with the exception of a few scattered pockets of survivors principally in the mountain of Bisesero, Kibuye, Southern Province. Due to the sheer numbers of Tutsi resident there, genocidal massacres had begun at a slightly slower pace in Kibuye prefecture. However through time, Kibuye prefecture became a target, resulting in vast numbers of Tutsi from the neighbouring areas fleeing to the Bisesero Region for refuge. Here they strove to resist their attackers. The historical reputation of the residents of Bisesero region as a warrior people had no doubt attracted Tutsis seeking protection to flee into the region. During the genocide, the Interahamwe established a base at Gishyita, which was a twenty-minute drive from the Bisesero mountains. This gave them easy access to their prey. ${ }^{80}$ The Tutsi people of Bisesero were poorly armed with one survivor, Emmanuel Masozera, stating that 'at the start of the killings we only had a few machetes and clubs but the killers were armed with guns and grenades. We also had stones to throw that the women had collected. The women were really truly brave. We didn't think it would last long'. ${ }^{81}$ The Interahamwe hunted down the Tutsi on the mountainside each day, withdrawing in the late afternoon. The cycle would begin again relentlessly each day, every day. Those endeavouring to resist the genocide at Bisesero would seek cover in the undergrowth, waiting until the militia were close at hand, and thereafter attempt to overcome them. But the Tutsi of Bisesero were no competition for the well-armed and wellfed Interahamwe.

Survivors of Bisesero indicate that by late June 1994, from the peak number of 65,000 people hiding in Bisesero, only about 2,000 remained alive. Witnesses describe these emaciated survivors as suffering from untreated wounds and hiding in caves or within the densely wooded forests. It was only a matter of time before these last survivors would succumb. Then, resisters of Bisesero learned from one of their few working radios that French soldiers had in fact arrived in Kibuye Prefecture, with a UN mandate to stop the genocide. In the words of one survivor, they thought their prayers had been answered. ${ }^{2}$

On arrival in Kibuye Prefecture, the French military established roadblocks and a headquarters post at Gishyita, a location that had coincidentally been used by thousands of 
Interahamwe as a meeting place for their daily assaults against the Tutsis in hiding in the Bisesero mountains. Robert Hakizimana, Jean Inyumba and Fabien Gara, former members of the Interahamwe, claim that they manned the roadblocks established by Operation Turquoise alongside French soldiers, and it was a common occurrence for civilians to be killed at the roadblocks, including women and children, in the presence of the French soldiers. ${ }^{83}$ Another former Interahamwe has detailed how French soldiers watched as the local Interahamwe leaders briefed the militias before organising their day's transportation into the 'killing fields' of the Bisesero mountains. ${ }^{84}$ Other ex-FAR and former Interahamwe claim that the French soldiers handed them guns and grenades and whilst they would move up the mountains on foot, other militia members were transported in French military buses, trucks or jeeps. ${ }^{85}$ Jean Inyumba reveals that once the génocidaires left the base at Gishyita, the French used military telescopes to monitor and direct the militia 'working' on the hillsides. ${ }^{86}$ When the Interahamwe returned to Gishyita each evening from the mountains, those in command would meet with the French soldiers at the military centre to inform them of the events of the day in Bisesero. ${ }^{87}$

On June 26 1994, several British journalists arrived in Kibuye and became aware of the situation at Bisesero. One of these journalists, Sam Kiley, informed the French soldiers at Gishyita that he was aware of the continuing slaughter at Bisesero and of his intention to forward an article to his editor that evening, detailing how massacres were continuing in the region despite the arrival of Operation Turquoise and the French. ${ }^{88}$ The following day, a member of the Interahamwe and a self-confessed killer was approached by French soldiers in Gishyita. He claims ' $[t]$ hey bought me a Primus [beer] and asked me to take them to Bisesero' ${ }^{89}$ The French were escorted mid-afternoon onto Bisesero mountain by a group of Interahamwe who travelled in a separate vehicle from the thirty or so French soldiers. Some of the Interahamwe were disguised, wearing uniforms of the Red Cross. A survivor of Bisesero who watched their arrival has stated:

"They had three cars, two of them [armoured personnel carriers] of French soldiers and the third car with the militia [Interahamwe] but it stopped a short distance away. We said 'lets go there' when the cars had separated and stopped. 'If they kill us they kill us'. Not long before they came, the Interahamwe had killed some of our people and they [the bodies] were near me. Three were dead but two were still hot. We went and picked them and took them to the French cars. One had been shot and two were dead by machetes. I talked to the French soldiers through the window of the car [APC's] and asked what help they could be to us. They stayed in their cars. They said they needed to know how many of us were here and said to bring everyone down out of the forests and onto the road"90. 
Another witness who survived the massacres at Bisesero told the author that they were so desperate, they were prepared to take the risk, despite seeing that the French had arrived accompanied by Interahamwe. Some of these militia were actually recognised as being responsible for massacres at Bisesero over the previous weeks. The survivors believed that they would be surely safe from the militia, as there were French helicopters circling above. Survivors of the genocide at Bisesero claimed that by using loudspeakers to hail people, 'the French were instrumental in talking the people out of their places of hiding':

'The French waited till we had done what they had asked and we were all out of hiding and gathered together on the road. They had started to look anxious. They just said "we cannot help you just now". They said they didn't have lorries and would have to leave, but promised they would come back soon. The French soldiers took the guns we had taken from the killers. We had eighteen guns but it did not matter because we had no ammunition and did not know how to work them. They must have thought we would be able to shoot our killers' ${ }^{91}$.

Rapidly, the survivors of Bisesero realised that the French troops that had arrived in the area appeared to be utterly disinterested in their plight. On his return to Kibuye one of the Interahamwe militia, Gusto, a former teacher who had escorted the French onto the Bisesero mountain, informed his leaders of the numbers and location of the remaining surviving Tutsi on the hillsides, and plans were made to destroy the last of the resisters. He claims that 'the French had no plans to save any of these Tutsi; our aims were the same - to kill the Tutsi. The French supported the mission of the Hutu'.$^{92}$ So it was that only hours after the arrival of the French at Bisesero, surviving Tutsis faced death at the hands of the Interahamwe whilst the French soldiers stood by.

Interestingly, Charles Uwinkindi, a survivor of Bisesero, claims that until they arrived in Bisesero, the French soldiers held to the line given from Paris that considered the Hutu to be the victims of genocide and not the Tutsi. However, having viewed the recently slaughtered bodies of Tutsi by the Interahamwe, some of the French soldiers quickly realised that it was the Hutu that were the perpetrators of the genocide. ${ }^{93}$ Sergeant Diego, the French non-commissioned officer in charge of the convoy that assembled the survivors of Bisesero, had earlier been briefed by his superiors that the Hutu were the victims. On his return to base that evening, he filed a report on his afternoon's findings and consulted his superiors within Operation Turquoise for direction. He fully expected to be returning to Bisesero at first light to evacuate those people (the Tutsi) who were clearly in mortal danger. Instead, he was prevented from taking such action by the direct orders of his superior officers. ${ }^{94}$ Diego made numerous phone calls to Paris but was frustrated by the resistance of higher military and government officials, who, despite Turquoise's alleged humanitarian mandate, seemed 
determined to resist intervention. The French sergeant took the decision to disobey the orders of his commanders, and, in the company of the French journalist Patrick de SaintExupéry, Diego departed camp in a convoy with his troops to return to Bisesero in an effort to evacuate the remaining survivors.

His efforts were frustrated however by the arrival of the head of the French special forces attached to Operation Turquoise, himself a veteran of Operation Noroit, who landed his helicopter on the road directly ahead of the convoy, thereby preventing their departure. ${ }^{95}$ It was two days later, on 30 June 1994, that Diego, accompanied by the same journalist and troops, once again disobeyed direct orders and returned to Bisesero where they found over one thousand people killed since their initial visit to the area some three days previously. Under pressure because of the presence of the media, their superior officers at base camp relented and steps were taken to rescue the few desperate survivors. ${ }^{96}$ From this, one must acknowledge that all evidence suggests that had the French acted in a manner appropriate to their mandate, many more of the people of Bisesero would have survived between $27-30$ June 1994.

Perhaps the negligence of Operation Turquoise at Bisesero is an extreme example, yet within the broader context of France's role in Rwanda in 1994 it can be seen as indicative of the approach of a section of the upper echelons in the French government.

By early July, the RPF were on the brink of a military victory. Rwandan Hutus were fleeing in their thousands across borders into refugee camps within Tanzania and Zaire; the interim government of Rwanda fled into the Humanitarian Safe Zone (SZH) of Operation Turquoise where looting was freely taking place under the gaze of the French. A former RPF soldier indicated that some French soldiers were actively stealing cars in Rwanda, that were then being resold in Zaire. ${ }^{97}$ France promised the international community that it would arrest the architects of the genocide who had by now fled into the $\mathrm{SZH}$, however, 'striving ...to keep open the possibility of future power-sharing negotiations, the French actually facilitated the safe passage to Zaire of the Hutu government, the army, and the militias'. ${ }^{98}$ In fact, a former Interahamwe commander has claimed that the French began rearming the genocidaires once they arrived in Zaire, with the plan to return to Rwanda and restore the regime overthrown by the FPR. ${ }^{99}$ This would fit with the fact that one British eyewitness has stated that the French soldiers who arrived in Butare in July evacuated Colonel Bagosora, flying him to Zaire on July 2, 1994. ${ }^{100}$ Bagosora was well known to the French military, having been responsible for establishing the militia group in early 1992 that became known as Interahamwe, and has indeed been charged with being one of the primary architects of the genocide of Tutsi. Colonel Théoneste Bagosora has since been convicted of crimes of genocide at the International Criminal Tribunal Rwanda. ${ }^{101}$ 
Operation Turquoise provides much scope for criticism of France. The stated humanitarian aims and objectives of the mission were barely fulfilled. Such was the need to remain credible in the eyes of France's African allies, many of whom were longstanding dictators and tyrants, that much of the actions of Turquoise were in reality directed towards the prevention of an RPF victory. The context of uneven democratisation across the continent, in some cases replacing leaders who had been in power for decades, alongside the emergence of the United States as the sole superpower is extremely important to note. A confidential newsletter, reputed to be from French government circles, showed the cynical disregard with which some of the French military and political establishment viewed the ongoing genocide. The article entitled 'Considerable political and geostrategic interests are hidden behind the Rwandese heap of corpses', argues that Rwanda was key to the whole Great Lakes region and could not be 'lost' to Anglophone influences. The newsletter ends as follows:

The region cannot be left in the hands of an English-speaking strongman [Paul Kagame] completely aligned to American views and interests. That is why, since 1990, France has supported the late President Juvénal Habyarimana in order to fight the RPF. It did not work out, so now the only choice left to us is to put back in the saddle the Zairian President Mobutu Sese Seko, the one man capable of standing up to Museveni' [and Kagame]. ${ }^{102}$

\section{Post-genocide French Rwandan relations}

Since 1994, Rwanda has repeatedly called for France to take responsibility for its role in the genocide. Kigali has been frustrated at every step. Indeed, in 2006 Rwanda broke diplomatic relations with France in response to the publication of a report by a French judge claiming that nine members of the RPF were responsible for the assassination of President Habyarimana, the event that sparked the genocide. Bruguière's claims have been provocative and heavily criticized by Le Figaro, Liberation, and other French newspapers. This criticism is owing to the sole evidence for Brugiere's claim being based on the testimony of a former member of the RPF, who is now hostile to the government of Rwanda, and a French government official with an obscure role in Rwanda pre-genocide but with responsibility for President Mitterand's wiretap department at the Elysee Palace. ${ }^{103}$

On August 5, 2008, a report was released by the Government of Rwanda that demonstrated the complicit role of France in the Rwandan genocide. The report was the culmination of three years of research by an independent commission, referred to earlier in this article as the Mucyo Commission. The report concluded that French government officials and the French military provided logistical support in 1994 to the interim Hutu government in Kigali. The most heinous charges included allegations that French soldiers raped Tutsi 
women, participated in both genocidal killings and political assassinations, and that Operation Turquoise provided active support to permit the Hutu génocidaires to flee the advancing RPF, escaping to the then Zaire.

During a visit to Rwanda in 2010, President Sarkozy acknowledged that France had made 'a grave error of judgement' and 'displayed a kind of blindness' ${ }^{104}$ But no apologies were made. This was followed in September of 2011, with President Kagame of Rwanda meeting President Sarkozy in Paris in an effort to bridge relations between their countries, ${ }^{105}$ and the release of a new French investigation by ballistics experts commissioned by the French judge Marc Trevedic to identify the location from where the surface to air missiles were launched that struck Habyarimana's jet. The publication of this ballistic report in 2012 removed much of the force from the allegations of six years previously that the RPF were responsible for the launch of the missiles. ${ }^{106}$

However, immediately prior to the commemorations marking the twentieth anniversary of the genocide in 2014, a deterioration in Franco-Rwandan relations occurred. The current tensions result from comments the Rwandan President Kagame made in an interview with Jeune Afrique in which he repeated his claim that France and Belgium had a direct role in the 'political preparation for the genocide and the perpetration of crimes of genocide'. ${ }^{107}$ As a result of the comments made, France was not represented at the official genocide commemoration ceremony in Rwanda in April 2014.

There are currently an estimated forty genocide suspects in France, more than in any other western country. These fugitives fled to France in the knowledge that they would be treated with impunity. ${ }^{108}$ Whitehouse claims that the reticence of France to pursue criminal proceedings is to avoid a focus on French foreign policy in Rwanda in the 1990s, which would reveal their complicity in the genocide. It is suggested there are currently twenty-eight on going investigations in France of Rwandan individuals suspected of crimes of genocide. One of those cases relates to that of Father Wenceslas Munyeshyaka who enjoys his own parish church in Gisors, France, and the safe haven France has provided for him since 2001. Father Wenceslas was indicted by the International Criminal Tribunal for Rwanda (ICTR) in 2005. The priest is accused of conspiring with leaders of the Interahamwe, writing up death lists, selecting Tutsi for extermination, being a willing bystander to Tutsis who had sought refuge within his church being removed and killed by Interahamwe and indeed there is substantial evidence that he raped young women throughout the period of the genocide. Refugees came to refer to Father Wenceslas Munyeshyaka as the 'Chaplain of the Militia'. The indictment was passed to the French justice system in 2005 but to date there has been no justice for the victims of Father Wenceslas. He has been arrested several times, but on each occasion he has been released with no further action. ${ }^{109}$ This is but one example of French 
reluctance to pursue justice for victims of the atrocities that took place in Rwanda, preferring instead to treat Rwandan fugitives in France with impunity.

\section{Conclusion}

Genocide does not occur without preparation, which includes ideological preparation in addition to practical, logistical and strategic efforts. Such preparation can be usefully described as conspiracy to commit genocide, which is a crime under international law in terms of Article III of the Genocide Convention. The ICTY has clearly indicated that any assistance in genocide constitutes sufficient participation to meet the terms of complicity as defined by the Genocide Convention.

This article has explored France's political and military relationship with Rwanda from 1990 and throughout the period of the genocide of 1994, highlighting the emergence of their complicity in genocide, revealing with special clarity that the French government overtly violated international law for political and economic advantage in central Africa. From 1990 onwards, France performed an integral role in the nascent architecture of the Rwandan genocide. France colluded and conspired with the Hutu regime, and it supplied arms and military equipment, military training as well as the indoctrination of hate ideologies to the FAR and Hutu militia organisations. Once the genocide in Rwanda commenced in April 1994, France knowingly persisted in its collusive, participatory role by continuing to deliver arms and military training to the génocidaires throughout the period of Operation Turquoise. This was, as noted previously, in breach of a UN arms embargo.

The French motivation for the proposal of the humanitarian intervention in Rwanda is highly questionable and again suggestive of complicity in the on going genocide. The policy of a French intervention in Rwanda was only adopted once it became apparent to them that France's chosen allies were on the point of being ousted by the RPF, viewed by the French as an 'Anglo Saxon' enemy. A victory by Paul Kagame was unpalatable to the French after its historically deep commitment to the Hutu regime. France was so fervid in its desire to block the RPF from halting the genocide and taking power in Rwanda that it pursued its role by deliberately and effectively forming a 'humanitarian intervention' as a cloak for the defence of its narrow state interests. As a by-product, the French intervention also facilitated the defeat of resistance in Bisesero, crushing the few remaining survivors on the mountainsides. The conduct of the French military at Gishyita is clearly definable as complicity in genocide and indicates that power interests rather than humanitarian concerns guided the French in Rwanda. It must be argued that there is potential for prosecution in terms under the concept of state crime.

While there has been some acceptance in the French Parliamentary report (1998) of French involvement in arming and equipping the government of Rwanda from 1990 - 1994, 
there has never been an open discussion between the two countries or an apology from France. Complicity in genocide by external governments must be tackled by prosecution, thereby enforcing the international laws and conventions on genocide. In this sense, the government of France has questions to answer with regard to it being held accountable by their informed constituencies for their conspiratorial and complicit role in the genocide in Rwanda.

This article concludes that to gain a greater understanding of genocide, it is essential to illuminate the actions not only of the genocidal state, but also the actions of those governments external to the country of genocide, whose policies are driven by their own national interests. This is a crucial, if relatively under-analysed, set of issues in the field of genocide studies and intervention. Greater insight into these dynamics is an essential step towards the prevention of future genocide.

In light of the evidence presented here, it is legitimate to question whether this atrocity could have been prevented if the government of France had expanded its national interests in Africa to include the welfare of ordinary Africans. It is only once criminologists and international jurists can begin to piece together all elements of the tragedy and instability in the Great Lakes Region that we will have a more realistic understanding of how international law might hold those responsible, through direct action or complicity, for one of the worst cases of genocide to blight human experience. Equally, such prosecutions-even of the "untouchables" - may make such actors think twice about their behaviour when similar tragedies occur in the future. ${ }^{110}$

\section{Acknowledgments}

My thanks to the Carnegie Trust for the Universities of Scotland for funding the fieldwork of this study. I would also like to express my gratitude to Professor Ian Taylor, University of St Andrews, for his exceptionally helpful comments on earlier drafts of this paper. 
1 Mark Levene, Genocide in the Age of the Nation State, Vol I: The Meaning of Genocide, (London and New York: IB Tauris, 2005), 201

2 Assemblee Nationale (1998), Mission d'information sur le Rwanda, available online at http://www.assemblee-nationale.fr/dossiers/rwanda/rapport.asp (last accessed 8 December 2014).The French Parliamentary Commission on Rwanda was invested early 1998, following a media led campaign and articles by journalist Patrick de Saint- Exupéry in the Figaro newspaper, calling for a detailed examination of the role of the French government in the events surrounding the 1994 genocide of Tutsi in Rwanda. 3 Organization of African Unity (OAU), Rwanda: The Preventable Genocide, (2000): para 12.8, available online at http://www.refworld.org/pdfid/4d1da8752.pdf : last accessed 18 December 2014

4 Names of all genocide survivors and perpetrators who were interviewed have been changed in this article to protect their identities.

5 A civilian death squad responsible for much of the killing of the Rwandan genocide. Interahamwe is Kinyarwanda, meaning "those who fight/work together".

6 In April 2005, Article 2 of the Organic Law of Rwanda (2004) established a 'Commission of Enquiry to Establish the Role of France in the Genocide of 1994' (herein referred to as Mucyo Commission), headed by the former Chief Prosecutor General and Minister of Justice, Jean De Dieu Mucyo. The Mucyo Commission was a domestic tribunal, made up of a seven-member panel of historians, legal experts and a senior military officer of the former Rwandan army. The Mucyo Commission gathered evidence at hearings throughout a seven-day period in October 2006 and a further seven day period in December 2006, the aim being to make formal recommendations to the government of Rwanda on whether or not to take legal action against France for genocide-related damages at the International Court of Justice.

7 Convention on the Prevention and Punishment of Genocide, Dec. 9, 1948, 78 U.N.T.s.277, reprinted in 45 American Journal of International Law, 7 (1951)

8 William, A. Schabas, Genocide in International Law, (Cambridge: Cambridge University Press, 2000), x

9 Reservations to the Convention on the Prevention and Punishment of the Crime of Genocide (Advisory Opinion), [1951] I.C.J. REPORTS 16, at 21, quoted in Legality of the Treat or Use of Nuclear Weapons (Advisory Opinion, [1996] I.C.J. REPORTS 226, 31. See also Report of the Secretary-General pursuant to 2 of the Security Council Resolution 808 (1993),

U.N. Doc. S/25704, 45.

10Schabas, 2000: 294

11 Negligence should not be confused with omission as an individual may intentionally omit to perform an act with the specific intent to destroy the group.

12 AKAYESU, Jean Paul (ICTR-96-4) http://www.unictr.org/Portals/0/Case/English/Akayesu/judgement/actamond.pdf

13 Schabas, 2000: 227

14 Ibid, 285

15 Ibid, 292-93

16 Pieter N. Drost, The Crime of State: Penal Protection for Fundamental Freedoms of Persons and Peoples, (Leyden: A.W. Sythoff, 1959

17 David Kauzlarich, Ronald C. Kramer, and Brian Smith, 'Toward the Study of Governmental Crime: Nuclear Weapons, Foreign Intervention, and International Law', Humanity and Society, 16, no 4 (1992) : 543 - 563 ; Nina Jorgensen, The Responsibility of States for International Crimes, (Oxford: Oxford University Press, 2000 ), 279

18 James Crawford, The International Law Commission's Articles On State Responsibility: Introduction, Text and Commentaries, (Cambridge: Cambridge University Press, 2002)

19 Refer to www.unictr.org for details of all judgements

20 Jorgensen, 2000: 35-6.

21 Ibid: 269.

22 For a more detailed discussion see Hazel Cameron, Britain's Hidden Role in the Rwandan Genocide: The Cat's Paw, (London: Routledge, 2012)

23 International Law Commission, 'Draft Articles on Responsibility of States for Internationally Wrongful Acts', report of its 53 rd Session (23 April - 1 June and 2 July - 10 August 2001), available online at: http://www.refworld.org/docid/3ddb8f804.html (Last accessed 4 April 2014)

24 Crawford, 2001, 89

25 International Law Commission, 2001; Crawford, 2002

26 International Law Commission, 2001

27 ibid

28 Daniela Kroslak, The role of France in the Rwandan genocide, (Manchester: Hurst \& Co., 2007) ; Gérard Prunier, The Rwanda crisis: History of a genocide (Columbia: Columbia University Press, 1995)

29 Mel McNulty, 'French arms, war and genocide in Rwanda', Crime, Law and Social Change, 33, (2000):105 - 129, pg 109

30 Ibid, 108

31 Human Rights Watch, Leave None To Tell The Story: Genocide in Rwanda (HRW Publications, 1999), available online at http://www.hrw.org/reports/1999/rwanda/ (Last accessed 4 April 2014

32 Alistair Cole, François Mitterrand: A Study in Political Leadership, (London: Routledge, 1997), 40. 
33 Andrew Wallis, Silent Accomplice: The Untold Story of France's Role in Rwandan Genocide, (London:IB Tauris, 2006), 20.

34 Helen Hintjens, 'Explaining the 1994 Genocide in Rwanda', The Journal of Modern African Studies, 37, no 2 (1999): 241-286

35 HRW, 1999

36 BrunoCharbonnea, France and the New Imerialism: Security Policy in Sub-Saharan Africa, (Aldershot: Ashgate Publishing Limited, 2008), 135

37 Kroslak, 2007

38 McNulty, 2000:109

39 Ibid: 110

40 Charbonneau, 2008: 126

41 Rwandan genocide survivor, interviewed by author, Kigali, Rwanda, 2005

42 Author interview with ex-FAR, Kigali, Rwanda, 2006

43 Mucyo Commission Report, Commission Nationale Independante Chargee De Rassembler Les Preuves Montrant L'Implication De L'Etat Francais Dans Le Genocide Perpetre Au Rwanda En 1994, Published by the Government of Rwanda 15 November 2007. http://www1.rfi.fr/actufr/images/104\%5CRapport_Rwanda.pdf (Last accessed 4 April 2014) 44 Allan Thompson, (ed), The media and the Rwanda genocide. (London: Pluto Press, 2007)

45 Author interview with ex-FAR, Kigali, Rwanda 2006

46 Author interview with ex-FAR, Kigali, Rwanda 2006

47 Author interview with former commander of Interahamwe, Kigali, 2015, currently serving a life sentence in a prison in Rwanda.

48 Kroslak, 2007, 134-139

49 Human Rights Watch Arms Project, 'Arming Rwanda: The Arms Trade and Human Rights Abuses in the Rwandan War', Human Rights Watch / Africa. Vol 6, No 1 (1994), 23 50 ibid

51 McNulty, 2000: 108

52 Human Rights Watch, 1999

53 On the evening of 6 April 1994 President Habyarimana of Rwanda and President Ntaryamira from Burundi returned to Kigali from a meeting in Tanzania to discuss implementation of the Arusha Peace Accords in Rwanda on board Hbyarimana's Falcon 50 jet. At 8.24pm, the Falcon jet began its descent towards Kigali airport when it was struck by two surface-to-air missiles which struck the jet. The jet turned into a fireball, the wrechage of which landed ironically in the grounds of Habyarima's own presidential palace. All occupants on board died instantly.

54 Despite international arrest warrants being issued for Mme Agathe Habyarimana, France has refused to extradite her to Rwanda to face trial.

55 Prunier, 1995: 234-236

56 Author interview with former commander of Interahamwe, Kigali, 2015, currently serving a life sentence in a prison in Rwanda.

57 BBC Panorama, 'The Bloody Tricolour', Broadcast in United Kingdom, 20 August 1995

58 Interview with former member of Interahamwe militia, Rwanda, 2006

59 S/RES/918. See http://daccessdds.un.org/doc/UNDOC/GEN/N94/218/36/PDF/N9421836.pdf?OpenElement

60 Patrick de Saint-Exupéry, 'L'inavouable: La France Au Rwanda', (Paris : Les arènes, 2004)

61 McNulty, 2000; See also Human Rights Watch Arms Project, 1994 for full details of the role of the French government in arming the perpetrators of genocide in Rwanda 62 David Bryer, 'A Letter to Prime Minister John Major', 3 May 1994, personal archive author; Wallis, 2006: 205

$63 \mathrm{~S} /$ RES/929 can be accessed in full at http://daccessdds.un.org/doc/UNDOC/GEN/N94/260/27/PDF/N9426027.pdf?OpenElement

64 Author interview with General Romeo Dallaire, London, 2006

65 Author interview with Lillian Wong, London, 2006

66 Author interview with Colin Keating, New York, 2006.

67 Author interviews in London with former members of UKMISNY, 2006

68 Interview with Lynda Chalker, London, 2006

69 Julian Nundy, ‘Balladur Takes a Moral Stance on Intervention' The Independent, 23 June 1994

70 Author interview with General Romeo Dallaire, London, 2005

71 Ibid

72 Author interview with survivor of the Rwandan genocide, Kigali, Rwanda, 2005

73 Author interview with General Romeo Dallaire, London 2005; Author interviews with survivors of the Rwandan genocide, Kigali and Bisesero, Rwanda $2005 / 2006$

74 Assemblee Nationale, Mission d'information sur le Rwanda, 1998

75 Author interview with genocide survivor, Kigali, 2006

76 Author interview with ex-FAR, Kigali, 2006

77 Author interview with former member of Interahamwe militia, Rwanda, 2006

78 Author interviews with former members of FAR and the Interahamwe militia, Kigali, Rwanda, 2006

79 Author interview with survivor of genocide, Kigali, Rwanda, 2006 
80 Author interview with former member of Interahamwe militia, Kigali, Rwanda, 2006

81 Author interview with genocide survivor, Bisesero, Rwanda, 2005

82 Author interviews with genocide survivors, Bisesero, Rwanda, 2005

83 Author interviews with former Interahamwe militia, Kigali, Rwanda, 2006

84 Author interview with former Interahamwe militia, Kigali, Rwanda, 2006

85 Author interviews with ex-FAR and former Interahamwe militia, Kigali, Rwanda, 2006

86 Author interview with ex-FAR, Kigali, Rwanda, 2006

87 ibid

88 Sam Kiley, 'UN dithers on Rwanda rescue as Tutsi hail French troops', The Times, 27 June 1994

89 Author interview with former Interahamwe militia, Kigali, Rwanda, 2006

90 Author Interview with survivor of genocide, Bisesero, Rwanda.

91 Author Interview with survivors of genocide, Bisesero, Rwanda

92 Author interview with former Interahamwe militia, Kigali, Rwanda, 2006

93 Author interview with survivor of genocide Bisesero, Rwanda, 2005

94 Saint-Exupéry, 2004:87

95 Ibid:83-84

96 Ibid: 89

97 Author interview with former RPF soldier, Kigali, Rwanda 2006

98 Alan, J. Kuperman, The limits of humanitarian intervention: Genocide in Rwanda, Washington DC: Brookings Institution Press, 2004.

99 Author interview with former commander of Interahamwe, Kigali, 2015, currently serving a life sentence in a prison in Rwanda.

100 Sam Kiley, 'A French Hand in Genocide', Times, London, April 9, 1998

101 see http://www.unictr.org/Cases/tabid/127/PID/10/default.aspx?id=4\&mnid=4 for judgement and sentencing

102 Prunier, 1995: 278-9

103 See Le Figaro, 22 November 2006, "Un magistrat provocateur", p.2

104 The Economist, Frenemies Forever, 17 September 2011, available online at http://www.economist.com/node/21529097, last accessed 8 December 2014 105 ibid

106 William Wallis, 'Rwanda Says Probe exonerates Kagame', Financial Times, London, January 12, 2012

107 Francois Soudan, 'Paul Kagame : “Le Rwanda n’a pas été fait pour moi”, Jeuneafrique, May 27, 2013

108 David Whitehouse, In Search of Rwanda's Génocidaires, (Ontario: Seraphim Editions, 2014)

109 See Chris McGreal, Chaplain of the Militia, (London: Guardian, 2014)

110 An earlier version of this article appeared in Hazel Cameron, Britain's Hidden Role in the Rwandan Genocide, (London: Routledge, 2012) 